\title{
Aberrant Regulation of Interleukin 18 Binding Protein A (IL-18BPa) by IL- 18BPa Autoantibodies in Rheumatoid Arthritis
}

\author{
Khalid KE ${ }^{1,2 \# *}$, Gue TB ${ }^{2 \#}$, Sun $\mathbf{W}^{2}$, Nie H², Liu A², Mohamed E M Ahmed ${ }^{3}$, Saeed OK ${ }^{4}$ and Zhang $\mathrm{JZ}^{2,5,6}$ \\ ${ }^{1}$ Department of Laboratory Medicine, Faculty of Applied Medical Sciences, Albaha University, Albaha-Saudi Arabia \\ Institutes of Biological Sciences, Chinese Academy of Sciences, China \\ ${ }^{3}$ Department of Surgery, Faculty of Medicine, University of Gezira, Medani, Sudan \\ ${ }^{4}$ Department of Internal Medicine, Faculty of Medicine, University of Gezira, Medani, Sudan \\ ${ }^{5}$ Department of Neuroimmunology, GlaxoSmithKline Research and Development Center, Shanghai, China \\ \#The first and the second authors are equally contributed to this study
}

${ }^{2}$ Joint Immunology Laboratory at the Institute of Health Sciences and Shanghai Institute of Immunology, Shanghai JiaoTong University School of Medicine and Shanghai

\begin{abstract}
Objective: This study aimed to identify the role of IL-18BPa in the regulation of immune responses associated with the pathogenesis of Rheumatoid Arthritis.

Methods: 65 Rheumatoid Arthritis (RA) patients, 22 Osteoarthritis (OA) patients, and 40 sex and age matched healthy donors were enrolled in this study. Synovial fluids mononuclear cells (SFMC) and peripheral blood mononuclear cells (PBMC) were prepared by using Ficoll-Hypaque separation procedure. Super Array analysis was used to measure the expression profile of immune-related genes in RA synovial tissues (RA-ST) and in normal PBMC treated with recombinant human IL-18 binding protein a (IL-18BPa). The mRNA levels of T-helper 1 (TH1) and T-helper 2 (TH2) cytokines were measured by real-time PCR, and the protein levels of IFN- $\gamma$, IL-4 and IL-18BPa autoantibodies were detected by ELISA.

Results: High expression of IL-18BPa protein and messenger RNA (mRNA) are found in RA-SF and RA-ST. SuperArray analysis of immune related gene expression profile in normal PBMC treated with IL-18BPa indicated decreases in the gene expression of IFN- $\gamma$. IL-18BPa downregulated the mRNA expression of IFN- $\gamma$ and IL-12, as well as, upregulated the mRNA expression of IL-4 and IL-10 in RA and normal subjects. IFN- $\gamma$ and IL-12 upregulated the mRNA and protein expression of IL-18BPa in RA subjects. Autoantibodies against IL-18BPa were detected in plasma of RA patients (41.7\%), in healthy subjects (4.0\%), and none of OA patients, and also detected in SF of RA patients $(37.9 \%)$ and OA patients $(9 \%)$.
\end{abstract}

Conclusion: This study emphasizes the anti-inflammatory properties of IL-18BPa on cytokines milieu and the IL-18BPa auto-antibodies may play a role in aberrant regulation of IL-18BPa in RA patients.

Keywords: IL-18BPa; Inflammation; Cytokines; Autoantibodies; Rheumatoid Arthritis; Osteoarthritis

\section{Introduction}

Rheumatoid Arthritis (RA) is a chronic inflammatory disease that affects approximately $1 \%$ of the population in all parts of the world [1]. Although the etiology and pathogenesis of RA is unknown, there is evidence indicating that T-cell mediated inflammation plays an important role in rheumatoid synovitis. Several data suggest that $\mathrm{T}$ lymphocytes, in particular, $\mathrm{T}_{\mathrm{H}} 1$ cells, and array of proinflammatory cytokines and monokines are associated with inflammation and tissue damage in RA $[2,3]$. Certain cytokines such as IL-18 has been found to exhibits powerful $\mathrm{T}_{\mathrm{H}} 1$ promoting activities in synergy with IL-12 in RA [4]. Still the molecular mechanisms involved in the activation and perpetuation of inflammatory $\mathrm{T}$ cells in rheumatoid synovium are poorly understood.

Novick et al. identified IL-18BPa as the natural inhibitor of IL18 [5]. This gene product is an important potential candidate for neutralizing IL-18 in autoimmune diseases [5-7]. As such, it regulates IL-18-induced IFN- $\gamma$ production and consequently influences the $T_{H} 1$ and inflammatory responses. IL-18BPa resembles the extracellular segment of a cytokine receptor in a single Ig domain. However, IL$18 \mathrm{BPa}$ is a novel protein distinct from IL-1 and IL-18 receptor family members.

Previous studies have implicated an increase in IL-18 and its neutralizing inhibitor (IL-18BPa) in RA serum, its expression in local areas of inflammation (e.g. RA synovial fluids or tissues) is quite interesting, since, there are an experimental evidences suggesting that IL-18BPa was not suffice to exert natural activity toward IL-18 [8-12] Furthermore, IL-18BPa expression in local areas of inflammation and its regulation during disease process and cytokine milieu is questionable, since the role of IL-18BPa as an early inhibitor of $\mathrm{T}_{\mathrm{H}} 1$ cytokines in animal models was indicated [13-16].

In this study, our preliminary data indicated the over expression of IL-18BPa in sunovial fluids and tissues of RA patients and that IL$18 \mathrm{BPa}$ has a proinflammatory role. In addition, our results suggest that the present of autoantibodies specific to IL-18BPa in RA synovium may play a role in disease persistence.

*Corresponding author: Khalid Eltahir Khalid Kheiralla, Department of Laboratory Medicine, Faculty of Applied Medical Sciences, Albaha University, P.O. Box 1988, Albaha, Saudi Arabia, Tel: +966506384596; Fax: +96677247272; E-mail: khatahir12@gmail.com

Received August 05, 2014; Accepted October 13, 2014; Published October 15 2014

Citation: Khalid KE, Gue TB, Sun W, Nie H, Liu A, et al. (2014) Aberrant Regulation of Interleukin 18 Binding Protein A (IL-18BPa) by IL-18BPa Autoantibodies in Rheumatoid Arthritis. J Arthritis 3: 140. doi:10.4172/2167-7921.1000140

Copyright: ( $) 2014$ Khalid KE, et al. This is an open-access article distributed unde the terms of the Creative Commons Attribution License, which permits unrestricted use, distribution, and reproduction in any medium, provided the original author and source are credited. 


\section{Methodology}

\section{Patients}

A total of 65 Chinese patients with RA, 22 patients with OA, and 40 sex and age matched healthy donors were enrolled in this study under the informed consent and the approval by the Institutional Medical Ethics Review Board of the Shanghai Institutes of Biological Sciences, Chinese Academy of Sciences. Diagnosis of RA and OA were defined according to the classification criteria of American College of Rheumatology [7]. All patients were from different parts of China, they referred to the Department of Rheumatology out clinic of Renji Hospital in Shanghai (China) in the period between 2009-2011. Patients received any immunosuppressive or immunomodulatory drugs at least two month preceding samples collection were excluded. RA patients include (58) female and (7) male with average age of (53 \pm 9.8 ), the summary of demographic and laboratory profiles of RA and OA subjects indicated in Table 1. Synovial specimens were obtained through synovectomy or arthroscopic procedures that were performed for other medical indications. Synovial Fluids (SF) were centrifuged at $350 \mathrm{~g}$ for 3 minutes, and supernatants were collected and immediately stored at $-80^{\circ} \mathrm{C}$ until use.

\section{Cell culture}

SF and peripheral blood samples were drawn from RA patients or healthy controls into heparnized syringes ( $20 \mathrm{U} / \mathrm{ml}$ final concentration) and subsequently PBMC were isolated by Ficoll-Hypaque density gradient centrifugation, cells were washed with RPMI-1640 medium (complete medium) supplemented with $25 \mathrm{mM}$ HEPES buffer and L-Glutamine, in addition to $10 \%$ heat-inactivated Fetal Calf Serum (FCS), $100 \mathrm{U} / \mathrm{ml}$ Penicillin, and $100 \mu \mathrm{g} / \mathrm{ml}$ Streptomycin (all purchased from GIBCO BRL Life Technologies, USA), after washing (well mixing) blood was added carefully over $7.5 \mathrm{ml}$ Ficoll-hypaque and centrifuged (Heraeus megafuge, 1.0, rotor) at $2000 \mathrm{rpm}$ without break for $20 \mathrm{~min}$ at $20^{\circ} \mathrm{C}$. Using a sterile pipette, the white belt between the two layers was sucked carefully. PBMCs were diluted 10 times its volume with PBS and counted by using cleaned slide covered hemocytometer. Briefly, $10 \mu \mathrm{l}$ of cell culture was dropped into the hemocytometer, and the cells were counted under the microscope in each corner square, averaged. Cells were adjusted to $1 \times 10^{6}$ cells $/ \mathrm{ml}$ and cultured in a 24 well plate (Becon Dickenson Labware Euorope), or adjusted to $0.2 \times 10^{6}$ cells/well in 96-flat bottom polypropylene well plates (Becon Dickenson Labware Europe). Culture supernatants and cells were collected from different plates for the analysis of IL-18BPa and cytokines by ELISA and/or Real-time PCR.

\section{Quantitative measure of cytokines}

Fresh PBMC from normal subjects were prepared as described before. $0.2 \times 10^{6}$ cells $/ \mathrm{ml}$ for 96 -flat bottom polypropylene well plates

\begin{tabular}{|l|c|c|}
\hline Parameters & RA (n=65) & OA (n=22) \\
\hline Age, mean years & $53 \pm 9.8$ & $70 \pm 8.3$ \\
\hline Disease duration, mean years & $10.6 \pm 6.6$ & $11 \pm 7.8$ \\
\hline Sex of (male/female) & $7 / 58$ & $4 / 18$ \\
\hline ESR mean mm/hour & $44.9 \pm 28.9$ & $26 \pm 13.6$ \\
\hline Positive Rheumatoid factor (\%) & 85.1 & NA \\
\hline IgG Rheumatoid Factor & $532.1 \pm 923.9$ & NA \\
\hline IgA Rheumatoid Factor & $454.0 \pm 608.1$ & NA \\
\hline C-reactive protein $(\mathrm{mg} / \mathrm{dl})$ & $19.43 \pm 18.1$ & NA \\
\hline
\end{tabular}

Table 1: Demographic and clinical data of the RA and OA patients referred to the out clinic of Renji Hospital in Shanghai in the period between September 20092011.
(Becon Dickenson Labware Euorope) were cultured for 48 hours. Cultured cells were stimulated with different concentrations of rIL$18 \mathrm{BP}(5,50,200 \mathrm{ng} / \mathrm{ml})$. After $48 \mathrm{hr}$ of stimulation, supernatants were assayed for cytokines using commercially available ELISA kits as specified; for of IFN- $\gamma$ and IL-4 (Jingmei Biotech-China).

\section{Quantitative measure of IL-18BPa}

Concentration of IL-18BPa in plasma and synovial fluid specimens was measured quantitatively using ELISA kit (R\&D Systems Incorporation) according to the manufacturer's procedure. For quantitative measure of IL-18BPa from culture supernatants prepared from RA-PBMC, a density of $0.2 \times 10^{6} \mathrm{cells} / \mathrm{ml}$ in $200 \mu \mathrm{l}$ RPMI 1640 medium were dispensed into 24 or 96 -flat bottom well plates (Becon Dickenson Labware Euorope). Different concentrations of human IFN- $\gamma(10 \mu \mathrm{g} / \mathrm{ml})$, and IL-12 $(10 \mu \mathrm{g} / \mathrm{ml})$, TNF- $\alpha(5 \mu \mathrm{g} / \mathrm{ml})$, IL-4 $(5 \mu \mathrm{g} /$ $\mathrm{ml})$, and IL-10 $(10 \mu \mathrm{g} / \mathrm{ml})$ were added to each well with anti-CD3 $(0.1$ $\mu \mathrm{g} / \mathrm{ml}$ ) antibodies (Takara-Japan). Cultures were incubated at $37^{\circ} \mathrm{C}$ in a humidified atmosphere consisting of $5 \% \mathrm{CO}_{2} / 95 \%$ air culture incubator (Heraeus) for 7 days. Culture supernatant and cells were collected from each well for the analysis of IL-18BPa by ELISA.

\section{Detection of IL-18BPa autoantibodies}

Purified recombinant Human IL-18BPa (human IgG1/Fc chimera) from R\&D systems and control goat anti-human IgG, F(ab) (Jackson ImmunoResearch) at $2 \mu \mathrm{g} / \mathrm{ml}$ in PBS for IL-18BPa auto-antibody detection. Plates were coated overnight at $4^{\circ} \mathrm{C}$, followed by blocking nonspecific binding sites with $10 \%$ (wt/vol) FBS for 1 hour and subsequently washed. SF, plasma or serum, along with the recombinant cytokines as standards, were diluted with PBS and added in duplicate wells. Plates were incubated for 2 hours and subsequently washed with PBS-Tween 20. Matched biotinylated detecting antibodies were added and incubated for 2 hours. After washing, avidin-conjugated HRP and 3,3',5,5-tetramethyl benzidine were used for color development. Optical density was measured and cytokine concentrations were quantitated using microplate computer software (Bio-Rad Laboratories).

\section{Super Array analysis}

The expression analysis of selected cytokines and chemokines genes were examined using a commercially available cDNA array system containing 364 genes related to autoimmune and inflammatory response and 20 positive and negative control genes (GEArray $S$ Series human autoimmune and inflammatory response gene array, SuperArray Bioscience Corporation, MD) according to the manufacturer's instructions. The gene list is given at the supplier's website (ww.superarray.com). Briefly, PBMC from healthy individuals were treated with IL-18BPa $(0.2 \mu \mathrm{g} / \mathrm{ml})$ for $48 \mathrm{hrs}$. Three micrograms of total RNA were reversed transcribed into biotin-16-deoxy-UTPlabeled single strand cDNA by Moloney murine leukemia virus reverse transcriptase. After pre-hybridization, membranes were hybridized with biotin-labeled sample cDNA and incubated with alkaline-phosphataseconjugated streptavidin. Chemiluminescence was visualized by autoradiography. The results were analyzed using GEArray Expression Analysis Suite (Version 1.0) provided by SuperArray at its website. The relative expression of different genes was estimated by comparing signal intensity with that of average intensity of internal control genes. Data was expressed as ratio of significant change in gene expression (IL-18BPa treated/untreated control).

\section{RT-PCR analysis}

Total RNA isolation was performed with RNeasy kits according to 
Citation: Khalid KE, Gue TB, Sun W, Nie H, Liu A, et al. (2014) Aberrant Regulation of Interleukin 18 Binding Protein A (IL-18BPa) by IL-18BPa Autoantibodies in Rheumatoid Arthritis. J Arthritis 3: 140. doi:10.4172/2167-7921.1000140

Page 3 of 7

the protocol from the manufacture (Qiagen). The purity of the RNA was quantified by absorbance $260 \mathrm{~nm}$ and purity was checked by 260 $\mathrm{nm}$ and $280 \mathrm{~nm}\left(\mathrm{OD}_{260} / \mathrm{OD}_{280}\right)$ absorbance and by agarose gel after staining with ethidium bromide. The cDNA were made by using the Sunsiscript RT kit (Qiagen) using RNA as a template. Synthesis was carried out in a $20 \mu \mathrm{l}$ reaction volume containing $4 \mu \mathrm{g}$ of total RNA, and random hexamers $(50 \mu \mathrm{M})$ were used as internal enzyme start sites. The reaction was performed by PCR (Biometra-Germany) for 60 minutes at $37^{\circ} \mathrm{C}$. Subsequently the enzyme "Sensiscript reverse transcriptase" was inactivated by heating the reaction mixture to $93^{\circ} \mathrm{C}$ for 5 minutes followed by rapid cooling in $4^{\circ} \mathrm{C}$, and stored in the same degree.

\section{Real-time PCR}

Real-time PCR analysis of cDNA is based on the direct detection of amplicons by signals. Production of signals was caused by the SYBR Green I dye into the real-time PCR reaction, which allows the

\begin{tabular}{|c|c|c|}
\hline Gene groups & Genes altered & Ratio \\
\hline \multicolumn{3}{|c|}{ Increased expression } \\
\hline \multicolumn{3}{|l|}{ Cytokines/Receptors } \\
\hline Interleukin-18 binding protein & & 7.3 \\
\hline Interleukin 1-beta & & 5.3 \\
\hline Interleukin 2 receptor, gamma & & 4.9 \\
\hline Interleukin3 & & 4.8 \\
\hline Interleukin 18 receptor 1 & & 2.3 \\
\hline \multicolumn{3}{|c|}{ Chemokines/Receptors } \\
\hline Chemokine (C-C motif) ligand 18 & & 16.4 \\
\hline Chemokine (C-C motif) ligand 5 & & 13.1 \\
\hline Chemokine (C-C motif) ligand 2 & & 4.8 \\
\hline Chemokine (C-C motif) ligand 19 & & 8 \\
\hline Chemokine (C-X-C motif), ligand 10 & & 6.4 \\
\hline Chemokine (C-X-C motif) ligand 13 & & 4.4 \\
\hline Chemokine (C-X-C motif) ligand 5 & & 3.3 \\
\hline \multicolumn{3}{|c|}{ Inflammatory factors } \\
\hline Rheumatoid factor RF-ET10 & & 15 \\
\hline Rheumatoid factor RF-IP4 & & 4.5 \\
\hline Collagen, type XIII, alpha 1 & & 4.8 \\
\hline Fibroplast growth factor 4 & & 2.3 \\
\hline Fibroplast growth factor 7 & & 3.9 \\
\hline Fibroplast growth factor 18 & & 4.5 \\
\hline Fibroblast growth factor receptor 3 & & 5 \\
\hline Integrin, alpha 2b (antigen CD41B) & & 4.1 \\
\hline Vascular cell adhesion molecule & & 3.7 \\
\hline Intercellular adhesion molecule 3 & & 3.3 \\
\hline \multicolumn{3}{|c|}{ CD markers \& Enzymes } \\
\hline Perforin 1 & & 11.6 \\
\hline Granzyme A & & 8.1 \\
\hline CD24 & & 4.7 \\
\hline CD86 (B7-2) & & 4.2 \\
\hline \multicolumn{3}{|c|}{ Increased expression } \\
\hline \multicolumn{3}{|l|}{ Cytokines/receptors } \\
\hline Interleukin 13 & & 3.8 \\
\hline Interleukin enhancer binding factor 2 & & 3.2 \\
\hline \multicolumn{3}{|l|}{ Chemokines/receptors } \\
\hline Chemokine (C-X-C motif) receptor 8 & & 2.5 \\
\hline \multicolumn{3}{|l|}{ Inflammatory factors } \\
\hline Integrin, type $V$, alpha 2 & & 5 \\
\hline Integrin, beta-like 1 & & 3.3 \\
\hline
\end{tabular}

Table 2: SuperArray analysis of immune-related gene expression profiles between RA and OA synovial tissues among Chinese patients referred to the out clinic of Renji Hospital in Shanghai.

\begin{tabular}{|c|c|c|}
\hline Gene groups & Altered genes & Ratio \\
\hline \multicolumn{3}{|l|}{ Description of increased genes } \\
\hline Colony stimulating factor 2 (granulocyte-macrophage) & & 79.51 \\
\hline Toll-like receptor 9 & & 5.02 \\
\hline Chemokine (C-X-C motif) ligand 6 & & 4.82 \\
\hline Vascular endothelial growth factor & & 3.73 \\
\hline Mitogen-activated protein kinase 8 & & 3.26 \\
\hline Forkhead Box P3 & & 2.34 \\
\hline Interleukin 12B & & 2.14 \\
\hline \multicolumn{3}{|c|}{ Description of decreased genes } \\
\hline Interferon, gamma & & 0.72 \\
\hline Suppressor of cytokine signaling 4 & & 0.58 \\
\hline Signal transducer and activator of transcription 4 & & 0.47 \\
\hline Chemokine (C-C motif) ligand 17 & & 0.41 \\
\hline CAMP responsive element binding protein 1 & & 0.36 \\
\hline Interleukin 9 & & 0.29 \\
\hline Signal transducer and activator of transcription 1 & & 0.21 \\
\hline Interleukin 19 & & 0.18 \\
\hline Inducible T-cell co-stimulator & & 0.16 \\
\hline Sp3 transcription factor & & 0.11 \\
\hline
\end{tabular}

Immune-related gene expression profile of normal PBMC treated with IL-18BPa activated with Anti-CD3 and Anti-CD28. PBMC from healthy individuals were treated with IL-18BP $(0.2 \mu \mathrm{g} / \mathrm{ml})$ for $48 \mathrm{hrs}$. The gene expression profile was compared with untreated PBMCs under the same experimental condition. Data were analyzed using GEArray Expression Analysis Suite (version 1.0) provided by SuperArray at its website (http://www.superarray.com). The results were representative of three experiments of different PBMC preparations, and given as a ratio of the expression different genes.

Table 3: Gene expression profile of normal PBMC treated with IL-18BPa.

\begin{tabular}{|c|c|c|c|}
\hline Name & Primer & Sequence (5'------3') & Product length(bp) \\
\hline \multirow{2}{*}{ IL-18BPa } & FW & acc tcc cag gcc gac tg & 342 \\
\hline & RV & cct tgc aca gct gcg tac $c$ & \\
\hline \multirow{2}{*}{$\mathrm{IFN}-\gamma$} & FW & tca gct ctg cat cgt ttt gg & 120 \\
\hline & RV & gtt cca tta tcc gct aca tct gaa & \\
\hline \multirow[t]{2}{*}{ IL-12 } & FW & tgg agt gcc agg agg aca gt & 147 \\
\hline & RV & tct tgg gtg ggt cag gtt tg & \\
\hline \multirow[t]{2}{*}{ IL-10 } & FW & gtg atg ccc caa gct gag a & 138 \\
\hline & RV & cac ggc ctt get ctt gtt tt & \\
\hline \multirow[t]{2}{*}{$\mathrm{IL}-4$} & FW & cca cgg aca caa gtg cga ta & 149 \\
\hline & RV & ccc tgc aga agg ttt cct tct & \\
\hline
\end{tabular}

FW: Forward; RV: Reverse; BP: Base pair

Table 4: Specific primers designed for real-time PCR (Q-PCR) analysis.

detection of any double-stranded DNA generated during PCR. Primers for IL-18BPa (published sequence AF110799), IFN- $\gamma$, IL-12, IL-10, and IL-4 were designed (Table 3 ) using the primer express software from Invitrogen Biotechnology Co., Ltd. The use of the hot-start enzyme AmpliTaq Gold ${ }^{\star}$ DNA polymerase in all SYBR Green I reagent kits allows the highest performance available by minimizing non-specific product formation. Glyceraldehyde-3-phosphate Dehydrogenase (GAPDH) (Invitrogen) was used as internal control. Primers for GAPDH were designed using the same software from Invitrogen according to the published sequence (M33197): forward $5^{\prime}$-gtg aag gtc gga gtc aac g-3'; reverse $5^{\prime}$-tga ggt caa tga agg ggt c-3. Real-time PCR was performed on the API Prism-Sequence detection system $7900 \mathrm{HT}$ (Applied Biosystems) as follows: initial holding at $50^{\circ} \mathrm{C}$ for 2 minutes, then $95^{\circ} \mathrm{C}$ for 10 minutes; this was followed by a 2-step PCR program: $95^{\circ} \mathrm{C}$ for 15 seconds and $60^{\circ} \mathrm{C}$ for 60 seconds for 40 cycles. Data were collected and quantitatively analyzed on an ABI PRISM 7900 sequence detection system (Applied Biosystems) (Table 4). The GAPDH gene was used as an endogenous control to normalize for differences in the 
amount of total RNA in each sample. All values were expressed as fold increase or decrease relative to the expression of GAPDH. The mean value of the replicates for each sample was calculated and expressed as cycle threshold (CT, cycle number at which each PCR reaction reaches a predetermined fluorescence threshold, set within the linear range of all reactions). The amount of gene expression was then calculated as the difference $(\Delta \mathrm{CT})$ between the CT value of the sample for the target gene and the mean CT value of that sample for the endogenous control $(\mathrm{GAPDH})$. Relative expression was calculated as the difference $(\Delta \Delta \mathrm{CT})$ between the $\Delta \mathrm{CT}$ values of the test sample and of the control sample. Relative expression of genes of interest was calculated and expressed as $2-\Delta \Delta \mathrm{CT}$

\section{Statistical analysis}

Experiments were performed in duplicate and triplicate. Results were expressed as the mean \pm SD of the indicated number of samples. Within group comparisons were analyzed by Student's paired $t$-test. An ANOVA and Mann-Whitney $U$ test corrected by Bonferroni method were used to determine the difference between different groups. Gene expression differences were analyzed by the Mann-Whitney U test. A $P$ value less than 0.05 were considered significant.

\section{Results}

PBMCs, Synovial Fluid (SF) Mononuclear Cells (SFMC), and Synovial Tissue (ST) specimens were obtained from clinically welldefined RA and OA patients and were analyzed and compared with control PBMCs derived from healthy individuals (Table 1). A preliminary result of the gene expression profile screening conducted in Synovial Tissue (ST) specimens obtained from RA patients compared with OA patients indicates an over expression to IL-18BPa gene profile (Table 2). As shown in Figure 1A, IL-18BPa protein was detected in SF derived from RA patients $(n=20)$, a level that significantly higher than that in OA-SF. As determined by the real time PCR, the expression of IL-18BPa was significantly elevated $(\mathrm{P}<0.001)$ in RA-ST compared with Orthoarthritis-ST (Figure 1B).

When we examined the expression profile of genes related to autoimmune and inflammatory response in normal subjects. An exvivo experiment representing the expression profile of selected genes of 20 positive and negative control genes in normal PBMC treated with IL-18BPa (GEArray S Series human autoimmune and inflammatory response gene array, SuperArray Bioscience corporation, MD). Notably,
IFN- $\gamma$ gene expression was decreased in treated PBMC compared to non-treated one (Table 3). From the aforementioned results, we hypothesized that IL-18BPa may has further anti-inflammatory property through decreasing the expression of $\mathrm{T}_{\mathrm{H}} 1$ cytokines such as IFN- $\gamma$. To this end, the in-vitro results in normal and RA-PBMCs indicate the ability of IL-18BPa to decrease the mRNA expression of IFN- $\gamma$ and IL-12 (Figures $2 \mathrm{~A} 1$ and A2) and protein levels of IFN- $\gamma$ (Figure 2B1), and it can augment the mRNA expression of IL-10 and IL-4 (Figure $2 \mathrm{~A} 3$ and A4) and the protein levels of IL-4 (Figure 2B2).

Next we examined whether blocking IL-18BPa in RA-SF could reverse the mRNA expression of IFN- $\gamma$ indicated in Figure 2 A1. SF of RA patients were pre-incubated for 45 min with different concentration of human anti-IL-18BPa antibody (R\&D System). PBMC cells were subsequently harvested and quantitatively analyzed. As indicated in Figure $2 \mathrm{~B} 3$, blocking IL-18BPa in RA-SF could reverse the mRNA expression of IFN- $\gamma$. Altogether, these results highlighted the antiinflammatory properties that IL-18BPa can play in RA synovium.

To see whether IL-18BPa can be induced by proinflammatory cytokines, RA-PBMCs were treated for 7 days with different concentration of IFN- $\gamma$, TNF- $\alpha$, IL-12, IL-23, IL- $1 \beta$, IL-4, and IL-10 with anti-CD3 antibody stimulation $(1 \mu \mathrm{g} / \mathrm{ml})$. As shown in Figure $3 \mathrm{~A} 1$ and 2 , IL-18BPa expression was significantly upregulated by IFN- $\gamma$ and IL-12 in a dose-dependant manner. In conformity, IFN- $\gamma$ and IL-12 could augment the production of IL-18BPa protein in-vitro in RA subjects (Figure 3B1 and B2). Our result indicates that IL-18BPa can be induced by a variety of proinflammatory cytokines.

The persistence of high mRNA and protein levels of IL-18BPa in RA synovium accompanied its high levels in RA serum [8], and the disease subsistence let us to postulate the presence of proteins or auto antibodies that may bind to and/or affect the anti-inflammatory properties of IL-18BPa.

In an attempt to demonstrate the presence of auto-antibody against IL-18BPa in plasma and SF of RA and OA patients, SF and plasma from $45 \mathrm{RA}$ patients, $20 \mathrm{OA}$ patients with OA and 25 normal subjects as control group were examined by a specific sandwich ELISA using plate coated with recombinant human IL-18BPa (human IgG1 Fc), autoantibodies binding to IL-18BPa were detected by goat anti-human IgG $\mathrm{mAb}$ with fragment specific for the $\mathrm{F}(\mathrm{ab}) 2$ to prevent its binding to the Fc part of IL-18BPa.

As shown in Figure 4A, elevated auto-antibodies to IL-18BPa were
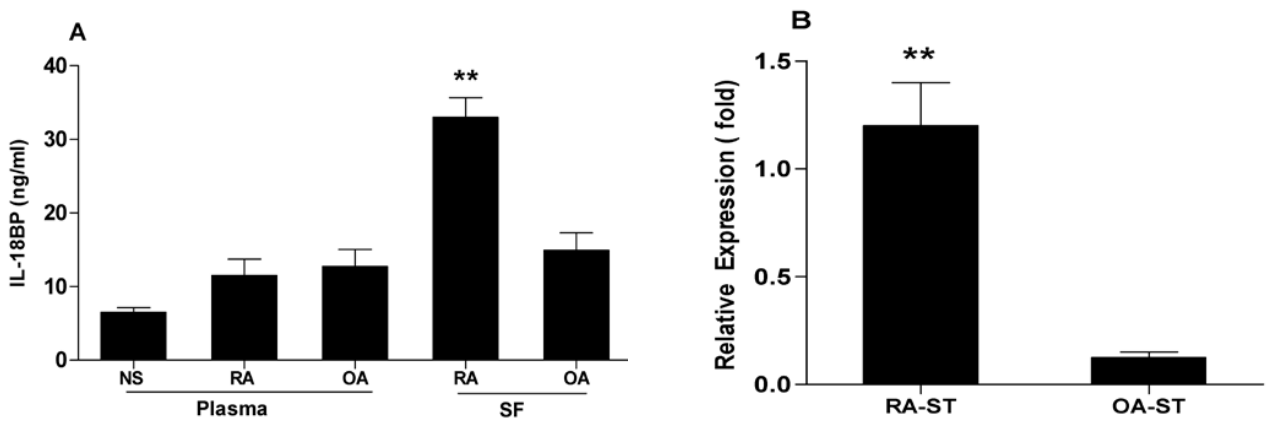

Figure 1: IL-18BPa mRNA and protein concentration in RA vs OA synovium. (A) The IL-18BPa protein concentration was measured by ELISA in 65 paired plasma and SF in RA and 22 OA patients. A panel of 40 plasma samples from healthy subjects was included as control. (B) RNA was extracted from ST of RA $(n=20)$ and OA $(n=10)$ for real time PCR. IL-18BPa expression was normalized to endogenously expressed GAPDH in the same samples. Relative expression was calculated as the difference between the $(\Delta \mathrm{Ct})$ values of the test sample and of the endogenous control (GAPDH). Results show the mean and SD of independent experiments performed in all study donors. Asterisks indicate statistically significant difference between the two groups $\left({ }^{* *} \mathrm{P}<0.001\right)$ 

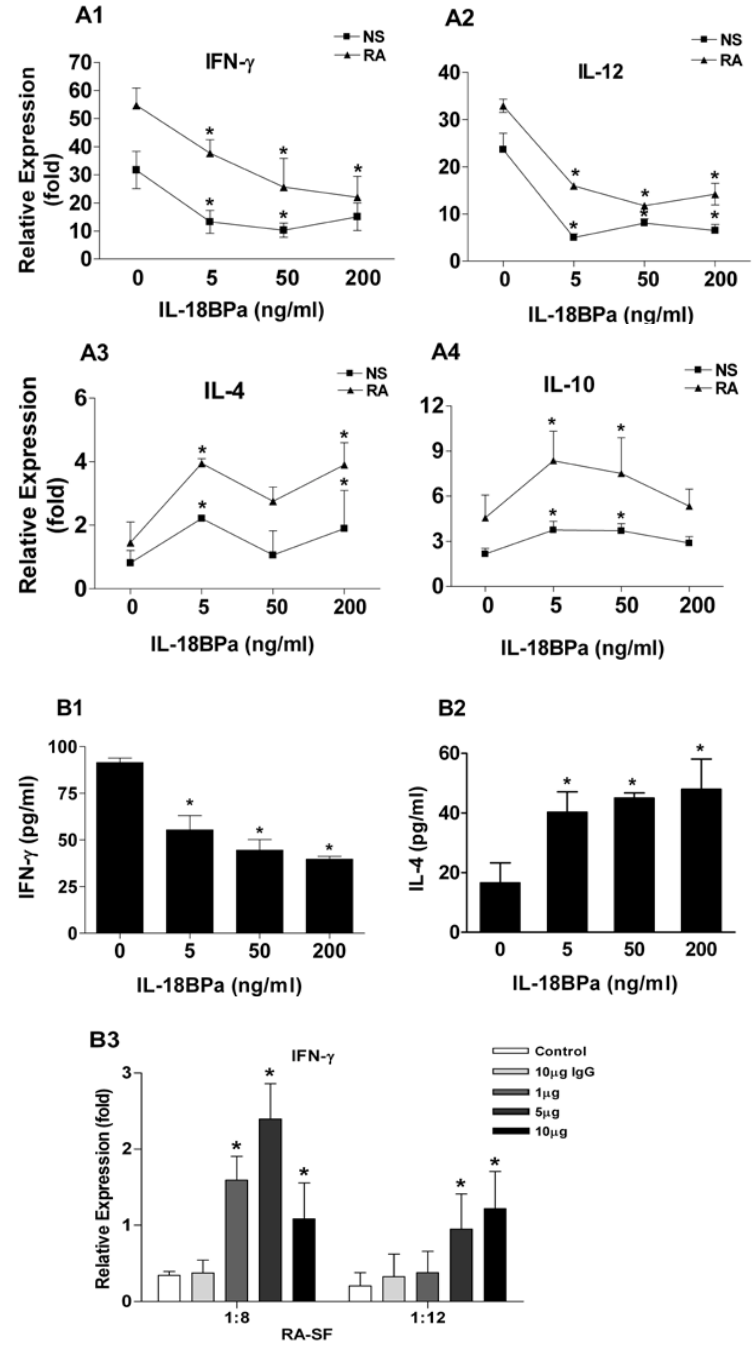

Figure 2: Regulatory effect of IL-18BPa on Th1 and Th2 mRNA transcripts and protein levels. (A1-5) PBMC from healthy Chinese donors $(n=20)$ and RA patients $(n=32)$ were cultured in flat bottomed wells at $1 \times 10^{6}$ cells $/ \mathrm{ml}$ in RPMI stimulated with different concentration of IL-18BPa $(5 \mathrm{ng} / \mathrm{ml}, 50 \mathrm{ng} /$ $\mathrm{ml}, 200 \mathrm{ng} / \mathrm{ml}$ ). After $48 \mathrm{hrs}$, IFN- $\gamma$, IL-12, IL-4, IL-10 were measured by real time PCR (Q-PCR). (B1\&2) Cytokines concentration of IFN- $\gamma$ and IL-4 in 48 hrs culture supernatant of normal PBMC was measured using ELISA. (B3) Normal PBMC was co-cultured with RA-SF pre-incubated with anti-human IL$18 \mathrm{BPa}$ antibody in a dose-dependant manner for $48 \mathrm{hrs}$, IFN- $\gamma$ mRNA was quantitated by Real-time PCR (Q-PCR). The results are expressed as mean value of relative mRNA expression of transcript \pm SEM. Single asterisk indicate significant different between the dose dependant concentration of IL-18BPa and the control $\left({ }^{*} \mathrm{P}<0.05\right)$.

detected in 25 out of 60 (41.7\%) plasma and 11 out of 29 (37.9\%) SF from patients with RA, while 2 out of $22(9.0 \%)$ in OA-SF and 2 out of $40(5.0 \%)$ in normal plasma were marginally positive. ELISA specificity to human IL-18BPa is evaluated by the pre-incubation of plasma from normal and RA subjects with soluble IL-18BPa, rather than control human IgG (Figure 4B). We used $0.443 \mathrm{OD}_{450}$ as a cut-off based on the mean $(0.249)+2 \mathrm{SD}(0.0972)$ of values with plasma from 40 normal donors at 1:2000 dilutions.

Taken to together, these results indicated for the first time, the presence of auto-antibodies specific to IL-18BPa which may play a role in the pathogenesis of RA.
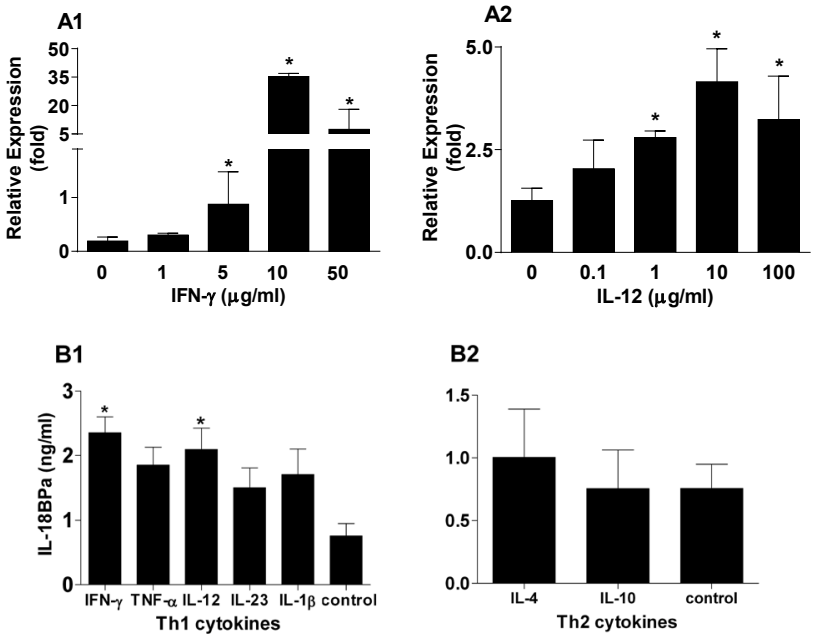

Figure 3: IL-18BPa production and mRNA expression by RA peripheral blood mononuclear cells (PBMC). PBMC $\left(1 \times 10^{6}\right.$ cells $/ \mathrm{ml}$ in RPMI 1640 medium with $10 \%$ fetal calf serum) from RA donors $(n=10)$ were cultured for 7 days in duplicate with IFN- $\gamma(1 \mu \mathrm{g} / \mathrm{ml}, 5 \mu \mathrm{g} / \mathrm{ml}, 10 \mu \mathrm{g} / \mathrm{ml}$, and $50 \mu \mathrm{g} / \mathrm{ml}), \mathrm{IL}-12(0.1 \mu \mathrm{g} / \mathrm{ml}$, $1.0 \mu \mathrm{g} / \mathrm{ml}, 10 \mu \mathrm{g} / \mathrm{ml}$, and $100 \mu \mathrm{g} / \mathrm{ml})$, TNF- $\alpha(1.0 \mu \mathrm{g} / \mathrm{ml})$, IL-23 $(1.0 \mu \mathrm{g} / \mathrm{ml}), \mathrm{IL}-1 \beta$ $(1.0 \mu \mathrm{g} / \mathrm{ml}), \mathrm{IL}-4(5 \mu \mathrm{g} / \mathrm{ml})$, and IL-10 $(10 \mu \mathrm{g} / \mathrm{ml})$. (A1\&A2) mRNA expressions were measured by real-time PCR. (B1\&B2) IL-18BPa Levels in the culture supernatants were determined by ELISA. Bars showed the significant levels as mean $\pm S D$ of total experiments performed with supernatant and cells from different healthy donors $(n=10)$. Asterisks indicate significant different $\left({ }^{*} \mathrm{P}<0.05\right)$.
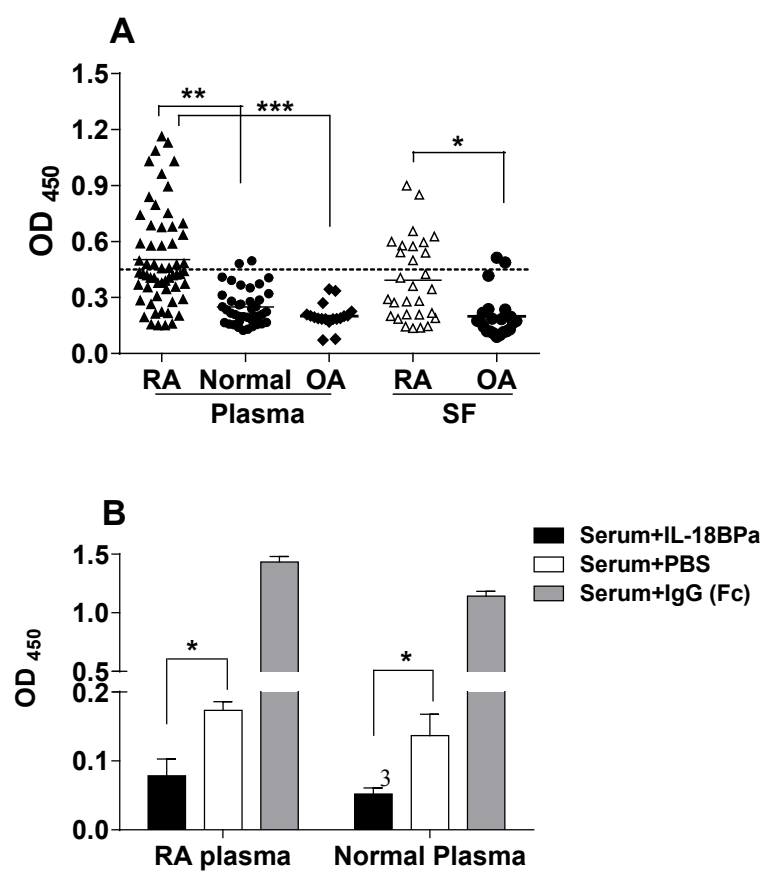

Figure 4: Detection of IL-18BPa auto-antibody in RA plasma and SF. (A) Diluted plasma and SF of RA and OA patients and plasma of healthy controls were tested for binding to IL-18BPa by ELISA. Samples with $\mathrm{OD}_{450}$ value greater than 0.443 were considered positive. (B) To examine the specificity of the RA plasma binding to IL-18BPa, diluted plasma were pre incubated with PBS, $2 \mu \mathrm{g} / \mathrm{ml}$ of soluble IL-18BPa or control lgG (hlgG1). Results are shown as mean and standards deviation (mean \pm SD) as representative data of one of two independent experiments. Asterisks indicate significant difference between experimental groups $\left({ }^{*} \mathrm{P}<0.05,{ }^{* *}, \mathrm{P}<0.01\right.$, $\left.{ }^{* * *} \mathrm{P}<0.000\right)$. 


\section{Discussion}

An increase in IL-18 and its neutralizing inhibitor (IL-18BPa) has been reported in RA serum compared with control $[8,9]$. Nevertheless, there is no observation regarding the protein level and expression of IL-18BPa in the local area of inflammation in RA. In this study we reported an overexpression and releases of IL-18BPa in RA synovium compared with $\mathrm{OA}$ and normal subjects a view supported by the superarray analysis in RA compared with OA synovial tissues [10-13].

The cDNA array gene analysis in normal PBMC treated with recombinant IL-18BPa reported down regulation to IFN- $\gamma$ gene production comparable with the Signal Transducer and Activator of Transcription 1 (STAT-1) and (STAT-4), which are involved in IFN- $\gamma$ production $[14,15]$. This notion let us to go deep and see whether IL$18 \mathrm{BPa}$ may has an effect on the cytokines milieu in RA and normal subjects, taken into account a previous studies highlighted in a way or another, an indirect inhibition of IFN- $\gamma$ by IL-18BPa [5], in addition to the function of IL-18BPa as an early inhibitor to $\mathrm{T}_{\mathrm{H}} 1$ cytokines in animal models following IL-18BPa administration in CIA models, and abrogate circulating IFN- $\gamma$ following LPS injection $[5,16]$. Furthermore, the level of IFN- $\gamma$ was found significantly reduced in serum of mice transgenic to IL-18BP compared to non-transgenic [17]. Also it has been found that the administration of IL-18BPa resulting in diminished the local production of IFN- $\gamma$ in patients with allergic contact dermatitis [18], and could reduce iNOS, TNF $\alpha$ and IFN- $\gamma$ in Rats model administered with IL-18BP antibody used as control group in kidney allograft rejection [19], in addition to restored the Ag-specific $\mathrm{T}_{\mathrm{H}} 2$ cells to produce IL- 4 and subsequently induce protective spread of $\mathrm{T}_{\mathrm{H}} 2$ polarization in EAE model [20]. In other compelling study, IL$18 \mathrm{BPa}$ was found down regulating IL-12 induced IFN- $\gamma$ production in RA- and normal PBMCs [21]. Compared to aforementioned results, here we observed an anti-inflammatory effect for IL-18BPa by reducing the release and expression of $\mathrm{T}_{\mathrm{H}} 1$ type cytokines represented in IFN- $\gamma$ and IL-12, as well as, IL-18BPa has the ability to upregulated the expression and production of $\mathrm{T}_{\mathrm{H}} 2$ type cytokines represented in IL-4 and IL-10. Furthermore, blocking IL-18BPa in RA-SF increased the expression of IFN- $\gamma$ in a dose-dependant manner.

Herein, we found that both IFN- $\gamma$ and IL-12 have the ability to enhance IL-18BPa production in a significant level, however, the other $T_{H} 1$ cytokines including IL-23, IL- $1 \beta$, and TNF- $\alpha$ can augment IL-18BPa production, together, the expression of IL-18BPa was significantly increased by IFN- $\gamma$ and IL-12 in a dose-dependant manner. Likewise, IL-18BPa was strongly expressed by IL-12 mediated through IFN- $\gamma$ in PBMC of healthy subjects [22]. However, only gamma interferon (IFN- $\gamma$ ) has the ability to up regulate the mRNA level of IL$18 \mathrm{BPa}$ in synoviocytes [23], endothelial cells and macrophages [3], and in non-leukocytes cells [24]. The discrepancy between our results and that reported by Kawashima and Miossec [21], who found IL-12 decreases the basal levels of IL-18BPa production by freshly isolated RA or control PBMCs, may be due to differences assay condition, and possibly, the different stimulation and application procedures used on their study.

IL-18BPa up-regulation correlated with the increase of IL-18 was previously reported in RA and Crohn's disease $[3,8]$. However the present of IL-18 in RA disease comparable with excess of IL-18BPa as reported in this study seemingly conflict with RA persistent. This puzzling raised the possibility that IL-18BPa may bind to or influenced by proteins or factors which may affect its biological activity toward IL-18. Since, IL-1H4 an IL-1 related protein has had a high degree of similarity to IL-18 $[25,26]$, it was there for possible that IL-1H4 could bind IL-18BPa. Aforementioned results let us to investigate for the possible presence of auto antibodies against IL-18BPa. Interestingly, our results documented for the first time a significant increase in IL$18 \mathrm{BPa}$ auto-antibody in the plasma and SF from RA patients compared with OA and normal control. This may provide another answer to the puzzling regarding the disease persistence even with IL-18BPa over expression particularly in RA.

In summary, in-vitro analysis indicated further anti-inflammatory properties to IL-18BPa on cytokines milieu, and IL-18BPa interaction with IFN- $\gamma$ and IL-12 could represent a negative feedback mechanism upon established RA inflammation. The detection of IL-18BPa autoantibodies may play a role in aberrant regulation of IL-18BPa in RA and possibly in other systemic autoimmune diseases. It also demonstrates that IL-18BPa based therapy can be a promising way for treating RA.

\section{Acknowledgment}

This study was supported by TWAS/CAS fellowship organization. We thank Dr. Wenxin Zheng, Xi Chen for technical assistant.

\section{References}

1. Buckley CD (1997) Science, medicine, and the future. Treatment of rheumatoid arthritis. BMJ 315: 236-238.

2. Banda NK, Vondracek A, Kraus D, Dinarello CA, Kim SH, et al. (2003) Mechanisms of inhibition of collagen-induced arthritis by murine IL-18 binding protein. J Immunol 170: 2100-2105

3. Corbaz A, ten Hove T, Herren S, Graber P, Schwartsburd B, et al. (2002) IL18-binding protein expression by endothelial cells and macrophages is upregulated during active Crohn's disease. J Immunol 168: 3608-3616.

4. Choy EH, Panayi GS (2001) Cytokine pathways and joint inflammation in rheumatoid arthritis. N Engl J Med 344: 907-916.

5. Novick D, Kim SH, Fantuzzi G, Reznikov LL, Dinarello CA et al. (1999) Interleukin-18 binding protein: a novel modulator of the Th1 cytokine response. Immunity 10: 127-136.

6. Szekanecz Z, Kim J, Koch AE (2003) Chemokines and chemokine receptors in rheumatoid arthritis. Semin Immunol 15: 15-21.

7. Aletaha D, Neogi T, Silman AJ, Funovits J, Felson DT, et al. (2010) 2010 Rheumatoid arthritis classification criteria: an American College of Rheumatology/European League Against Rheumatism collaborative initiative. Arthritis Rheum 62: 2569-2581.

8. Bresnihan B, Roux-Lombard P, Murphy E, Kane D, FitzGerald O, et al (2002) Serum interleukin 18 and interleukin 18 binding protein in rheumatoid arthritis. Ann Rheum Dis 61: 726-729.

9. Yamamura M, Kawashima M, Taniai M, Yamauchi H, Tanimoto T, et al. (2001) Interferon-gamma-inducing activity of interleukin-18 in the joint with rheumatoid arthritis. Arthritis Rheum 44: 275-285.

10. Lonnemann G, Novick D, Rubinstein M, Dinarello CA (2003) Interleukin-18 interleukin-18 binding protein and impaired production of interferon-gamma in chronic renal failure. Clin Nephrol 60: 327-334.

11. Liang D, Ma W, Yao C, Liu H, Chen X (2006) Imbalance of interleukin 18 and interleukin 18 binding protein in patients with lupus nephritis. Cell Mol Immunol 3: 303-306.

12. Ludwiczek O, Kaser A, Novick D, Dinarello CA, Rubinstein M, et al. (2002) Plasma levels of interleukin-18 and interleukin-18 binding protein are elevated in patients with chronic liver disease. J Clin Immunol 22: 331-337.

13. Fantuzzi G, Banda NK, Guthridge C, Vondracek A, Kim SH, et al. (2003) Generation and characterization of mice transgenic for human IL-18-binding protein isoform a. J Leukoc Biol 74: 889-896.

14. Afkarian M, Sedy JR, Yang J, Jacobson NG, Cereb N, et al. (2002) T-bet is a STAT1-induced regulator of IL-12R expression in naïve CD4+ T cells. Nat Immunol 3: 549-557.

15. Lawless VA, Zhang S, Ozes ON, Bruns HA, Oldham I, et al. (2000) Stat regulates multiple components of IFN-gamma-inducing signaling pathways. J Immunol 165: 6803-6808. 
Citation: Khalid KE, Gue TB, Sun W, Nie H, Liu A, et al. (2014) Aberrant Regulation of Interleukin 18 Binding Protein A (IL-18BPa) by IL-18BPa Autoantibodies in Rheumatoid Arthritis. J Arthritis 3: 140. doi:10.4172/2167-7921.1000140

16. Plater-Zyberk C, Joosten LA, Helsen MM, Sattonnet-Roche P, Siegfried C, et al. (2001) Therapeutic effect of neutralizing endogenous IL-18 activity in the collagen-induced model of arthritis. J Clin Invest 108: 1825-1832.

17. Lonnemann G, Novick D, Rubinstein M, Dinarello CA (2003) Interleukin-18, interleukin-18 binding protein and impaired production of interferon-gamma in chronic renal failure. Clin Nephrol 60: 327-334.

18. Plitz T, Saint-Mézard P, Satho M, Herren S, Waltzinger C, et al. (2003) IL-18 binding protein protects against contact hypersensitivity. J Immunol 171: 11641171.

19. Wyburn K, Wu H, Chen G, Yin J, Eris J, et al. (2006) Interleukin-18 affects local cytokine expression but does not impact on the development of kidney allograft rejection. Am J Transplant 6: 2612-2621.

20. Schif-Zuck S, Westermann J, Netzer N, Zohar Y, Meiron M, Wildbaum G, Karin N (2005) Targeted overexpression of IL-18 binding protein at the central nervous system overrides flexibility in functional polarization of antigen-specific Th2 cells. J Immunol 174: 4307-4315.
21. Kawashima M, Miossec $P$ (2004) Decreased response to IL-12 and IL-18 of peripheral blood cells in rheumatoid arthritis. Arthritis Res Ther 6: R39-39R45.

22. Veenstra KG, Jonak ZL, Trulli S, Gollob JA (2002) IL-12 induces monocyte IL-18 binding protein expression via IFN-gamma. J Immunol 168: 2282-2287.

23. Möller B, Paulukat J, Nold M, Behrens M, Kukoc-Zivojnov N, et al. (2003) Interferon-gamma induces expression of interleukin-18 binding protein in fibroblast-like synoviocytes. Rheumatology (Oxford) 42: 442-445.

24. Mühl H, Kämpfer H, Bosmann M, Frank S, Radeke H, et al. (2000) Interferongamma mediates gene expression of IL-18 binding protein in nonleukocytic cells. Biochem Biophys Res Commun 267: 960-963.

25. Kumar S, McDonnell PC, Lehr R, Tierney L, Tzimas MN, et al. (2000) Identification and initial characterization of four novel members of the interleukin-1 family. J Biol Chem 275: 10308-10314.

26. Pan G, Risser P, Mao W, Baldwin DT, Zhong AW, et al. (2001) IL-1H, an interleukin 1-related protein that binds IL-18 receptor/IL-1Rrp. Cytokine 13: 1-7. 